Made in United States of America

Reprinted from Copeis, 1978, No. :

(1) Copyright, 1978, by the American Society of Ichthyologists and Ilerpetoiogists

\title{
A New Marlin, Makaira panamensis, from the Late Miocene of Panama
}

\author{
Harry L. Fierstine
}

\begin{abstract}
Makaira panamensis new sp. is described from a single neurocranium found in the Chagres Sandstone (Late Miocene) of the Atlantic coast of Panama. The new species is closely related to and possibly ancestral to the extant $M$. indica (black marlin) and $M$. nigricans (blue marlin). It differs from both by possessing a triangular rather than elongate basioccipital foramen, large nutrient canals in the rostrum and probably a more elongate orbit. The fossil is compared to all known fossil istiophorids as well as to the living marlins. It is suggested that the black marlin is a more recent derivative (than the blue marlin) that was unable to thrive in the Atlantic Ocean because of a temperature barrier.
\end{abstract}

$\mathrm{F}^{\mathrm{s}}$ OSSIL marlins and sailfishes (Istiophoridae) are known from a few rostral fragments and isolated vertebrae described from African, European and North American deposits (Aram. bourg, 1927; Barbolani, 1910; Casier, 1966; Fierstine, 1974; Fierstine and Applegate, 1968; Woodward, 1901). The fragmentary nature of these specimens has contributed little to our knowledge of extant billfishes. The recovery of a relatively complete neurocranium from the Late Miocene of Panama is of much interest because the specimen could bear significantly on the evolution and zoogeography of the living species.

The specimen described herein was collected by Robert H. Stewart from the Chagres Sandstone of Late Miocene age on the Atlantic shoreline of Panama, approximately $17 \mathrm{~km}$ southwest of Colon, Canal Zone. A discussion of the geology and invertebrate paleontology of the Chagres Sandstone is given by Woodring $(1957,1970$ and 1973).

\section{Materials}

Recent osteological material was compared with the fossil specimens. The species, length, locality, collection number and kind of material were: Istiophorus platyplerus, length unknown, off Cabo San Lucas, Baja California, CPSLO 76-4, neurocranium; 1 . platypterus, length unknown, locality unknown, UCLA S549, neuro- cranium; I. platypterus, $2,520 \mathrm{~mm}$ fork length, off Baja California, HLF 105, rostrum; Makaira indica, length unknown, locality unknown, UCLA \$551, complete vertebral column and neurocranium; $M$. nigricans, $3,280 \mathrm{~mm}$ fork length, Indian Ocean, BRUNN 565.60, complete skeleton; $M$. nigricans, $2,231 \mathrm{~mm}$ total length, off Kailua-Kona, Hawaii, CPSLO 76-1, rostrum; $M$. nigricans, $2,243 \mathrm{~mm}$ total length, off Kailua-Kona, Hawaii, CPSLO 76-2, rostrum; M. nigricans, $2,762 \mathrm{~mm}$ total length, off KailuaKona, Hawaii, CPSLO 76-3, rostrum; Tetrapturus angustirostris, length unknown, off Monterey, California, SIO 59.287-43A, complete skull; $T$. audax, off southern California, Cerritos College Collection, complete skull; $T$. audax, $1,900 \mathrm{~mm}$ total length, locality unknown, UCLA S281, neurocranium; T. audax, length unknown, off San Clemente Island, California, HLF 54, rostrum.

Abbreviations for repositories or catalogue numbers of examined material are: AMNHAmerican Museum of Natural History, BMNHBritish Museum (Natural History), CPSLOCalifornia Polytechnic State University (San Luis Obispo), HLF-personal collection of the author, BRUNN-Anton Brunn cruise (National Museum of Natural History), LACMLos Angeles County Museum of Natural History, MNHNP-Museum National d'Histoire Naturelle (Paris), IRSNB-Institut Royal des 


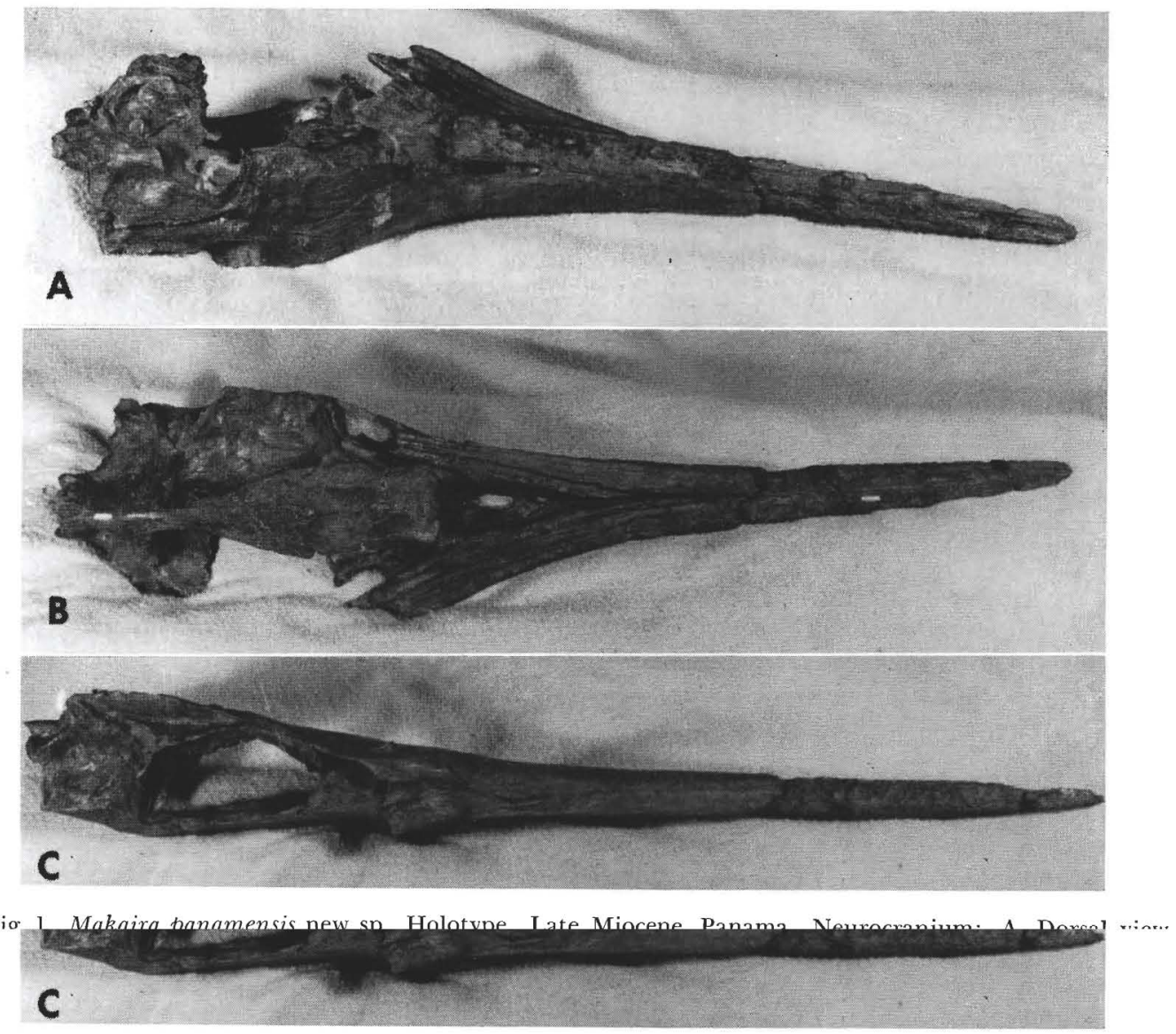

Fig. 1. Makaira panamensis new sp., Holotype. Late Miocene, Panama. Neurocranium: A. Dorsal view, B. Ventral view, C. Lateral view.

Sciences Naturelles de Belgique, UCLA-University of California, Los Angeles, SIO-Scripps Institution of Oceanography.

Makaira panamensis new sp. Figs. 1, 2, 4c

Holotype.-National Museum of Natural History, Vertebrate Paleontology collection (USNM) 181710. A nearly complete neurocranium and rostrum with slight dorso-ventral compression and torsion. Chagres Sandstone, Late Miocene, Canal Zone, Panama, Central America, $9^{\circ} 17^{\prime} \mathrm{N}$ $+988 \mathrm{~m}, 80^{\circ} 02^{\prime} \mathrm{W}+457 \mathrm{~m}$.

Diagnosis.-The fossil is assigned to Makaira rather than to Istiophorus or Tetrapturus (1) because of its large size, (2) because of the acute parasphenoidal angle (Fig. 3), and (3) because the dorsal wall of the myodome is wider than the height of the sidewalls. The fossil is intermediate in certain respects between the only two living species: Makaira indica (Cuvier) (black marlin) and Makaira nigricans Lacépède (blue marlin). It differs from both the black marlin and blue marlin by possessing a triangular rather than an elongate basioccipital foramen, large nutrient canals in the rostrum and probably a more elongate orbit as well as a more depressed skull (distortion during pres-

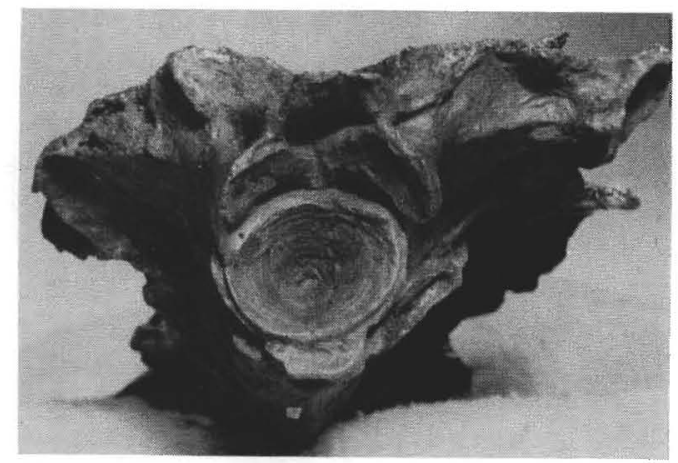

Fig. 2. Makaira panamensis new sp., Holotype. Late Miocene, Panama. Posterior view of neurocranium. 
ervation makes accuracy of these proportions questionable). It differs from the black marlin in having low, paired ridges on the dorsal surface of the supraoccipital and only a small anterior projection on the vomer rather than a large one. The fossil differs from the blue marlin in having the dorsal surfaces of the exoccipital bones together forming a broad posterior projection rather than a narrow, tapering projection. In addition, the fossil probably differs from the blue marlin by possessing a proportionately larger myodome.

Description.-The neurocranium is nearly complete except that the left half of the skull roof and approximately the distal one-fourth of the rostrum is missing. There is some dorso-ventral compression and torsion that has resulted in lateral displacement of the left maxillary and clockwise rotation of the occipital region (when viewed posteriorly). The overall length of the specimen (from basioccipital centrum to tip of rostrum) is $903 \mathrm{~mm}$, but the total length when the rostrum is reconstructed is estimated to be $1,200 \mathrm{~mm}$. The greatest depth of the skull, $107 \mathrm{~mm}$, is located between the pineal swelling on the skull roof and a point anterior to the parasphenoidal angle. The greatest width is $187.5 \mathrm{~mm}$ (measured across the pterotics), but the probable greatest width of the reconstructed neurocranium (measured across the posterior border of the orbit) is estimated to be $230 \mathrm{~mm}$. The length of the neurocranium (post-rostral length) from the anterior edge of the orbit to the posterior edge of the basioccipital condyle is $247 \mathrm{~mm}$.

Description and comparisons with living forms.Most of the sutures of the fossil neurocranium cannot be distinguished, thus the relative position of one bone to the other is not emphasized. Because of the specialized and incomplete nature of the fossil, I divided the neurocranium into seven morphological regions for description and comparisons (rostrum, skull roof, orbit, lateral otico-occipital, myodome, ventral neurocranium and posterior occipital). I was unable to use the standard method of measuring billfishes (Rivas, 1956) because the fossil material was too fragmentary. Makaira panamensis is compared with other marlins, but this portion of the study is limited by lack of a comparative series of osteological specimens. The definition of the various measurements used herein is given in Fig. 3 or in the text. The osteological

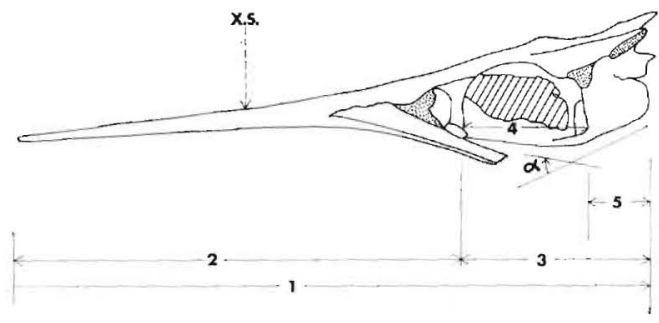

Fig. 3. Lateral view of generalized istiophorid skull (after Gregory, 1933) illustrating certain measurements used in this study. Overall length (1), rostral length (2), post-rostral length (3), length of ventral border of orbit (4), postorbital length (5), parasphenoidal angle $(\alpha)$, approximate level of cross sections in Fig. 4 (X.S.).

nomenclature follows Gregory and Conrad (1937).

Rostrum.-The rostrum or bill is principally composed of the premaxillary bones, but the ethmoid, frontals, lateral ethmoids, maxillaries, nasals and vomer contribute to part of its structure at the proximal end. Due to compression, the specimen is distorted and the left premaxillary has been displaced laterally. Approximately $240 \mathrm{~mm}$ of the distal end and the left dorso-lateral portion of the distal onehalf of the rostrum are missing. The length (from the orbital boundary of the lateral ethmoid to the tip) is $713 \mathrm{~mm}$ and when the missing tip is added, the reconstructed rostrum is estimated to be $953 \mathrm{~mm}$ long. Reconstruction was made easy because the rostrum tends to taper evenly from the orbit to its distal tip. The denticles (as evidenced by alveoli) appear to be restricted to the ventral and lateral surfaces of the rostrum. In cross-section (measured 565 $\mathrm{mm}$ from the orbit) the rostrum is oval-shaped measuring $32 \mathrm{~mm}$ in height and an estimated $42 \mathrm{~mm}$ in width. At its base (at the level of the anterior extension of the maxillary), the rostrum tends to be more depressed than those of the two extant species (see proportional relationships in Table 1); however, this may be due to distortion during fossilization. Two large oval-shaped nutrient canals (each measuring 8.5 $\mathrm{mm}$ high and $5 \mathrm{~mm}$ wide) are located slightly ventral to the center. These canals are approximately twice as large and more oblong than the nutrient canals housed in the rostrum of the blue marlin and black marlin (Fig. 4). When the height of a canal is divided by the height of the rostrum (Fig. 4), the proportions 

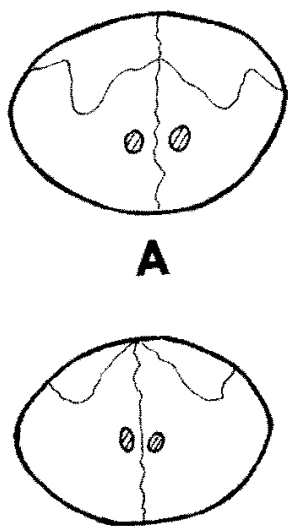

B

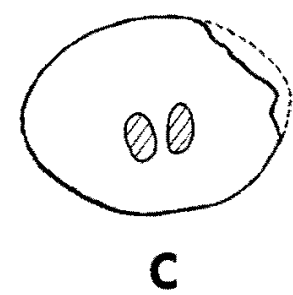

Fig. 4. Cross sections of rostra showing size and placement of nutrient foramina. Approximate level as indicated in Fig. 3. A. Makaira indica, UCLA \$551; B. Makaira nigricans, BRUNN 565-60; C Makaira panamensis new sp., USNM 181710, holotype.

are: black marlin, .123 (UCLA S55I); blue marlin, 138 (BRUNN 565.60); Panama marlin, .265. Due to the lack of data, it is not known if these proportions are different because of allometric growth.

In order to determine the taxonomic importance of the size of the nutrient canals, rostra of three recent specimens were sectioned at various places perpendicular to their long axis: blue marlin, CPSLO 76-3; sailfish [Istiophorus platypterus (Shaw and Nodder)], HLF-105; striped marlin [Tetrapturus audax (Philippi)] HLF-54. Each had a pair of small diameter nutrient canals that progressively decreased in diameter toward the tip, but extended the entire length of the rostrum. At the approximate level indicated in Fig. 3, the diameters (along longest axis) were $5 \mathrm{~mm}$ (sailfish), $3 \mathrm{~mm}$ (blue marlin); and $2 \mathrm{~mm}$ (striped marlin). When the canal diameters were divided by the height of the rostrum, the proportions were .312 (sailfish), .111 (blue marlin) and .125 (striped marlin).
Thus, the sailfish rostrum has proportionately the largest nutrient canals of any species so far studied.

The exact borders of the ethmoid, frontals, lateral ethmoids and nasals cannot be distinguished in the fossil, but it appears that these bones are similar in position and proportions to those in extant marlins (Makaira).

The maxillary bones are represented only by their anterior halves. Each has a large condyle that articulates with a large facet on the vomer. As in other marlins, the maxillaries converge anteriorly toward the mid-line to form a symphysis. The symphysis is separated in the fossil as a result of distortion during fossilization.

Skull roof.-The right balf of the roof is nearly complete, whereas most of the left half is missing. The following description is based on the right side, unless otherwise noted. In general the features are similar to those found in other istiophorids.

The frontal bone has surface sculpturing that radiates anteriorly from a point midway above the orbit. Posteriorly each frontal bone forms the anterior limits of two longitudinal, dorsolaterally projecting crests, each of which terminates posteriorly in pterotic and epiotic processes. Most of the frontal covering the pineal is missing, but there is enough present to indi. cate that there was a thin, bulging roof covering this region as in all istiophorids. The frontal also forms the anterior limits of two longitudinal fossae, one located between the two longitudinal crests and the other located lateral to the lateralmost longitudinal crest.

The parietal bone cannot be distinguished, although it is presumed to be present. The epiotic process that forms the posterior portion of the medial longitudinal crest is missing. The dorsal surface of the supraoccipital has two low, longitudinal ridges $(40 \mathrm{~mm}$ long) that are separated $17 \mathrm{~mm}$ anteriorly and $8.5 \mathrm{~mm}$ posteriorly. These ridges are present on the blue marlin, striped marlin, sailfish and shortbill spearfish (Tetrapturus angustirostris Tanaka), although they tend to be more nearly parallel. The ridges are absent in the black marlin.

The pterotic bone is neanly complete except for the portions that form the posterior part of the lateral longitudinal crest and the dorsal border of the hyomandibular socket.

Orbit--The large oval right orbit is more or less complete along its margins except for its anterior border which lacks most of the lateral 
ethmoid. The margins of the left orbit are quite incomplete. The shape of the right orbit is probably distorted because of the dorsoventral compression and torsion that occurred during fossilization. When this distortion is linked with the absence of the right lateral ethmoid, the typical orbital measurements (horizontal length, height) are unreliable. In order to obtain a more meaningful and undistorted measurement for comparative purposes, the length of the ventral border of the orbit was taken from the angle between the ascending process of the parasphenoid and its horizontal (palatal) process and the angle between the parasphenoid and the lateral etlimoid (Fig. 3). Length of the ventral border of the orbit is $155 \mathrm{~mm}$ and is $62.8 \%$ of the postrostral length (Table 1, Fig. 3). This percentage is somewhat larger than the percentages determined for the black marlin (56.4\%) and the blue marlin $(55.4 \%)$. Distortion during fossilization, however, may have increased the length of the orbit in the Panama marlin.

According to Rivas (pers. comm.) the orbit diameter, expressed as the percent of the snout length (anterior tip of lower jaw to the anterior border of the orbit), is significantly smaller in black marlin than in blue marlin. The snout length cannot be determined on the fossil, but the length from the anterior edge of the condyles on the vomer to the anterior edge of the bony orbit was used as a comparable measurement. When the ventral border of the orbit of the fossil and comparative osteological specimens was expressed as the percent of the "snout" (vomer to orbit) length (Table 1) there were no differences.

Lateral otica-occipital region.-Although this region is poorly preserved, it seems quite similar to those of other istiophorids. The pterotic, sphenotic and prootic form a fossa for one of the two heads of the hyomandibular bone. Laterally the exoccipital contains a large glossopharyngeal foramen. Ventral to the anterior hyomandibular facet (formed by the sphenotic and prootic), the prootic presents a laterally projecting keel which forms the posterior border of the orbit. Although incomplete, this postorbital shelf seems to have contained the trigeminofacialis clumber as well as a foramen (or at least a notch) for the lateral head vein.

Myodome.-The myodome is a deep, tetrahedralshaped fossa beneath the floor of the braincase. It opens anteriorly by a triangular entrance that has its base dorsad and its apex ventrad. The base is longer than the sides (Table 1 ) and longer than the anteroposterior length (depth) of the fossa. The volume of the myodome was obtained by determining the volume of dry aquarium sand required to fill it. The size of the myodome in the fossil and the black marlin is proportionally larger than in the blue marlin as evidenced by the ratio of myodome depth to post-orbital length (Table 1).

Ventral neurocranium.-The ventral side of the neurocranium consists of the unpaired basisphenoid, parasphenoid and vomer. The basisphenoid is a thin, vertical Y-shaped bone 10cated in front of the myodome. The base of the $\mathrm{Y}$ articulates with the parasphenoid and each wing of the $Y$ articulates with the pterosphenoid and prootic. The blue marlin and black marlin (as well as sailfish, shortbill spearfish and striped marlin) have a small, thin bony brace between the parasphenoid and the posterior border of the basisphenoid. In the fossil there is a low roughened area on the parasphenoid that may be a remnant of this bony brace.

The parasphenoid is a large bone that extends anteriad from the occipital region to the vomer. The exact posterior limit is not visible, but the parasphenoid forks around a pear-shaped basioccipital foramen (to be discussed below). Just posterior to the orbit, the parasphenoid has paired dorsal projections and each contains at its base the foramen for the internal carotid artery. At the posteroventral border of the orbit, the anterior portion of the parasphenoid makes a $20^{\circ}$ angle (parasphenoidal angle in Fig. 3) with the posterior portion. The anterior three fifths is flat and makes a wide U-shaped articulation with the vomer.

The vomer is a massive bone that articulates posteriorly with the parasphenoid, laterally with the lateral ethmoids, dorsally with the ethmoid and anteriorly by two large condyles, one for each maxillary bone. The condylar surfaces are ovoid and have relatively flat facets that face anterolaterally. Unlike the black marlin, there appears to be only a slight anterior projection between the maxillary condyles; however, it is possible that this projection was not preserved during fossilization. This projection may be a variable feature because a large blue marlin (BRUNN 565-60) lacks such a structure, whereas two smaller blue marlins (CPSLO 76-1 \& 76-2) have slight projections. 
Table 1. Comparative Measurements (mM) and Proportional Relationships of the neurocrania of Makaira indica (Black Marlin), M. nigricans (Blue Marlin) and $M$. panamensis New Sp.

\begin{tabular}{|c|c|c|c|}
\hline & $\begin{array}{l}\text { M. indica } \\
\text { UCLA S551 }\end{array}$ & $\begin{array}{l}\text { M. nigricans } \\
\text { BRUNN 565-60 }\end{array}$ & $\begin{array}{l}\text { M. panamensis } \\
\text { USNM } 181710\end{array}$ \\
\hline \multicolumn{4}{|l|}{ GENERAL } \\
\hline Greatest depth & 127.0 & 116.0 & 107.0 \\
\hline Greatest width & 210.0 & 193.0 & 230.0 (est.) \\
\hline Overall length & - & 998.0 & $1,200.0$ (est.) \\
\hline Postorbital length & 90.0 & 76.0 & 89.0 \\
\hline Postrostral length & 236.0 & 202.0 & 247.0 \\
\hline \multicolumn{4}{|l|}{ ROSTRUM } \\
\hline Height at the anteriormost extension of maxillary & 34.0 & 39.0 & 40.8 \\
\hline Width at the anteriormost extension of maxillary & 48.0 & 45.0 & 69.5 \\
\hline Length (from anterior border of orbit) & - & 800.0 & 713.0 \\
\hline \multicolumn{4}{|l|}{ ORBIT } \\
\hline Horizontal length & 133.0 & 117.0 & 139.0 \\
\hline Vertical height & 87.0 & 81.0 & 64.5 \\
\hline Ventral border length & 133.0 & 112.0 & 155.0 \\
\hline \multicolumn{4}{|l|}{ OCGIPITAL } \\
\hline Height of basioccipital centrum & 40.6 & 33.4 & 38.7 \\
\hline Width of basioccipital centrum & 46.5 & 43.2 & 51.2 \\
\hline Width of exoccipital extension & 29.0 & 19.0 & 29.0 \\
\hline Length of exoccipital extension & 17.2 & 15.0 & 6.9 \\
\hline Greatest width of basioccipital foramen & 6.0 (est.) & 8.0 & 15.4 \\
\hline Length of basioccipital foramen & 24.7 (est.) & 26.0 & 18.3 \\
\hline \multicolumn{4}{|l|}{ MYODOME } \\
\hline Depth & 51.0 & 39.0 & 50.0 \\
\hline Dorsal wall length (base) & 65.9 & 60.0 & 67.1 \\
\hline Sidewall length & 49.2 (est.) & 48.0 (est.) & 52.9 \\
\hline Volume & $45 \mathrm{ml}$ & $30 \mathrm{ml}$ & $50 \mathrm{ml}$ \\
\hline \multicolumn{4}{|l|}{ VENTRAL NEUROCRANIUM } \\
\hline Width of vomer (through maxillary condyles) & 70.3 & 57.0 & 77.3 \\
\hline Length of vomer & 136.0 & 107.0 & 133.0 \\
\hline Length of anterior extension of vomer & 17.0 & 0.0 & 5.0 \\
\hline Parasphenoidal angle & $12.5^{\circ}$ & $21.5^{\circ}$ & $20.0^{\circ}$ \\
\hline \multicolumn{4}{|l|}{ PROPORTIONAL RELATIONSHIPS } \\
\hline Myodome depth/Postorbital length & .567 & .513 & .562 \\
\hline Ventral border of orbit/Postrostral length & .564 & .554 & .628 \\
\hline Postorbital length/Postrostral length & .381 & .376 & .360 \\
\hline Height of rostrum/Width of rostrum & .708 & .866 & .587 \\
\hline Ventral border of orbit/"Snout" & 1.51 & 1.51 & 1.49 \\
\hline
\end{tabular}

Posterior occipital region.-The basioccipital centrum is oval (wider than high) and is deeply concave. Unlike the black marlin, the centrum does not form the ventral border of the basioccipital, but instead is located $9.7 \mathrm{~mm}$ dorsad. Each exoccipital bone forms a large posterior projecting zygapophysis that contains an ovoid facet that faces posteroventrolaterally. This facet on both the blue marlin and black marlin faces much more posteriad; this difference, however, may be due to the depression caused by fossilization. Dorsally each exoccipital forms an 
arch over the foramen magnum. This arch has a broad posterior projection over the basioccipital centrum. A slight dorsal ridge is formed at the junction of the two exoccipital bones at the mid-line. Laterally each exoccipital forms a narrow dorsolateral ridge of bone that points toward the otic region. Above this ridge is the foramen for the vagus nerve and below this ridge is the glassopharyngeal foramen.

Etymology.-panamensis, refers to Panama, the location of the type-locality.

\section{Discussion}

Comparison with fossil forms.-Fossil istiophorids have been described from Eocene, Miocene, Pliocene and Pleistocene deposits with most of the descriptions being based upon isolated rostra. Because most species are known from single specimens, there has been a general reluctance to section the rostra in order to study the size, shape, number and position of the nutrient foramina, even though these foramina have been used as familial and subordinal characters and have potcntial value at the generic level. There have been no comparative studies of rostra for the recent species. With the above limitations I will compare Makaira panamensis with the other fossil forms.

Various workers have placed seven fossil species in lstiophorus (the sailfish genus). In my opinion these were arbitrary decisions and the specimens could have been placed in either one of the other two living genera (Makaira or Tetrapturus). However, until such time as comparative rostral studies have been made, I shall leave those fossil species in Istiophorus. Catalogue numbers are given for those specimens examined by me. The holotypes of I. antiqus, $I$. homalorhamphus and $l$. parvulus have not been located, but probably are among the uncurated paleontological collection of the Academy of Natural Sciences, Philadelphia (letter dated 18 April 1977 from Dave Gillette, College of Idaho, Caldwell, Idaho).

Istiophorus cocaenicus Woodward, 1901, (BMNH 25744, holotype, Middle Eocene of England) is a rather short and stout rostrum. In cross section it has two pairs of small foramina on each sile of the mid-line and apparently at least one small central foramen. Distally the rostrum is solid is cross section. The presence of more than one pair of foramina makes me suspect that the specimen is either a xiphiorhynchid or a primitive istiophorid near the xiphorhynchid-istiophorid divergence.

Istiophorus rotundus Woodward 1901 (BMNH P8799, holotype, EEocene of South Carolina) is a very stout and round rostrum and is the most massive specimen for its length $(913 \mathrm{~mm})$ that I have seen. It has not been sectioned, but it is very different in shape from any known istiophorid.

Istiophorus antiquus (Leidy, 1855) (Eocene greensand of New Jersey) has been reclassified and briefly discussed by Cope (1869) and mentioned by Fowler (1911). Based upon the descriptions, the rostrum seems to belong to a large istiophorid, but no mention is made of nutrient foramina.

Istiophorus homalorhamphus (Cope, 1869) (Eocene or Miocene greensand of New Jersey) has been figured and briefly discussed by Fowler (1911). According to the published accounts, the rostrum is slender, more or less round in cross section and has one pair of large, round nutrient canals visible at its prox imal end. The denticles in two fairly wide rows distinguish it from other istiophorids.

Istiophorus parulus (Marsh, 1870) (Upper Cretaceous or Eocene greensand of New Jersey) is a very slender, compressed, short rostral frag. ment with denticles in two bands. Based upon the description, the specimen is probably not an istiophorid and belongs to what I have called the "Cylindracanthus" group (Fierstine, $1974)$.

Istiophorus calvertensis Berry, 1917, (USNM 9344, holotype, FMiocene, Calvert formation, Virginia) is a moderately slender rostrum that is transversely oval in cross section. It contains one pair of nutrient canals that are more elongate in cross section than those of $M$. pan. amensis.

Istiophorus robustus (Leidy, 1860) (AMNH, Pleistocene of South Carolina) is a short, slender rostral fragment that was refigured by Hussakof (1908). Based upon published accounts, the specimen is oval in cross section (long axis dorsoventral), but this may be due to preservation. There is no indication of nutrient foramina, but the denticles are probably restricted to the ventral surface (dorsal surface in Leidy's figure, but the specimen is probably upside down). The shape of the cross section distinguishes this specimen from other istiophorids.

The genus Brachyrhnchus Van Beneden, 
1871, was synonymized with Istiophorus by Woodward (1901) and Barbolani (1910), but resurrected by Leriche (1926). I shall follow Woodward (1901) and synonymize all Brachy. rhynchus with Istiophorus. Four species are involved.

Istiophorus teretirostris (Van Beneden, 1871) (?Middle Miocene of Belgium, exact locality un. known) is a large, elongate rostrum with paired nutrient canals that are smaller than those of $M$. panamensis. The description was based on a cast and an artist's drawing of the specimen; the disposition of the type is not known.

Istiophorus solidus (Van Beneden, 1871) (IRSNB P643, holotype, Upper Eocene, Ghent, Belgium) is a short rostral fragment with one pair of moderately large nutrient canals that are placed more towards the periphery, more rounded and smaller in cross section than those of $M$. panamensis.

Istiophorus belgicus (Leriche, 1926) (IRSNB P1117, holotype, Mio-Pliocene, Anvers, Belgium) is a rostral fragment that in cross section is flatter on the dorsal surface than an the ventral surface. The paired mutrient canals are smaller in diameter and closer to the dorsal surface than those of $M$. panamensis.

Istiophorus vanbenedensis (Lawley, 1876) (Lower Pliocene, Orciano, Italy) is an elongate and slender rostrum that was redescribed and refigured by Barbolani (1910). The location, morphology and number of nutrient canals are not known, but the specimen is much more slender than the rostrum of $M$. panamensis.

Arambourg (1927) described a new billfish, Xiphiorhynchus courcelli (MNHNP 250, holotype, Lower Pliocene, Algeria) based upon two rostra and various fragments. Each rostrum contains one pair of nutrient canals (in some cross sections two additional tiny canals are visible). To be consistent with the above discussion, these specimens should be considered as Istiophorus courcelli (Arambourg. 1927). The rostra are more depressed (long axis of the oval cross section is transverse) than the rostrum of M. panamensis.

Few fossil specimens have been placed in an extant genus other than Istiophorus or in an extant species. Rarbolani (1910) placed all spccies of Brachynhynchus as well as several other rostra into the living Istio phorus herschelit (Gray, 1838) which has been synonymized with the blue marlin (Makaira nigricans Lacépede, 1802) by Nakamura et al. (1968). One specimen (rostrum number 3 of Barbolani, 1910) may have been placed in the correct genus (Makaira) based upon general morphology and large size of the rostrum, but the species identification cannot be substantiated. While in Italy in the spring of 1975 I was unable to obtain permission to study the specimens described by Barbolani (1910) and presumably housed at the University of Bologna.

Fierstine and Applegate (1968) described a rostral fragment (LACM 17693, Late Miocene, Orange County, California) as belonging to Makaira sp. This specimen has nutrient canals about one half the size of those of $M$. panamensis, i.e. more similar to those of the extant species.

Evolution of the marlins (Makaira)-Based primarily upon the cranial osteology of $M$. panamensis, some of the primitive features of Makaira are: large overall size, an acute parasphenoidal angle, low paired ridges on the supraoccipital, a well-developed rostrum with one pair of large diameter mutrient foramina, a well-developed myodome and pineal swelling, broad posterior extension of exoccipitals, a large triangular basioccipital foramen, probably a more elongate orbit as well as a more depressed skull. The black marlin and blue marlin share the following primitive characters: large overall size, an acute parasphenoidal angle, well-devel. oped rostrum, well-developed myodome and pineal swelling; and the following derived characters: one pair of small diameter nutrient foramina in the rostrum and a slit-like basioccipital foramen. Of the two extant species, the black marlin alone possesses the following primitive character: a broad posterior extension of exoccipitals; and the following derived characters: anterior extension of the vomer, loss of paired ridges on the supraoccipital, a more acute parasphenoidal angle, a smaller orbit. The blue marlin alone possesses no special primitive characters, but does possess the following derived characters: narrow tapering posterior extension of exoccipitals; anterior cxtension of vomer in smaller specimens; orbit diameter intermediate in size between those of the black marlin and Panama marlin.

The few differences between blue marlin and black marlin and the retention of many primitive characters by these species speak in favor of close relationships among the three species of Makaira and support the view that all should be placed in a single genus. It is assumed that the Panama marlin is ancestral to at least one 
of the extant species, if not both. I suggest that the black marlin was derived more recently than the blue marlin for the following reasons: 1) its derived characters are elaborations of those seen in the blue marlin and 2) it is excluded today from the Atlantic Ocean, but was not during earlier times (see discussion below).

There is some disagrcement among fishery scientists as to whether there are one or two species of blue marlins. Nakamura et al. (1968) and Nakamura (1974) hold that there is an Atlantic form, $M$. nigricans, and an Indo-Pacific form, M. mazara (Jordan and Snyder). Robins and de Sylva (1960), Howard and Ueyanagi (1965) and Rivas (1975) agree that these two forms at most represent subspecies of a single pantropical species of blue marlin (M. nigricans) occurring in the Atlantic, Pacific and Indian oceans. I have followed the latter authors in this paper. Unfortunately, the discovery of $M$. panamensis does not help solve this problem.

Zoogeographical implications.-According to Rivas (1975) the distribution of the blue marlin is mostly confined to the tropics by the $24 \mathrm{C}$ surface isotherm of the Atlantic, Indian and Pacific oceans. The black marlin is also widely distributed in the Indian and tropical Pacific oceans, but only occasionally strays around the Cape of Good Hope into the southeastern Atlantic Ocean (Nakamura, 1975; Rivas, pers. comm.). Nakamura (1975) suggested that the optimum surface temperature for black marlin is greater than $23 \mathrm{C}$, thus the two marlins have similar surface temperature optima. These two different distribution patterns raise several questions: 1) Why isn't the black marlin more common in the South Atlantic Ocean? 2) Was the black marlin once more widely distributed in the tropical Atlantic? 3) Is the distribution pattern of black marlin expanding, contracting, or static? and 4) Was the past distribution of blue marlin similar to its present pattern?

In answer to question number one, Penrith and Cram (1974) discussed the Cape of Good Hope as a barrier to billfishes and concluded that favorable hydrographic conditions exist during the summer for movement of billfishes (and other large oceanic fishes such as tunas) into the South Atlantic. They suggested that an innate behavior pattern, possibly established in the earlier history of the area, may be keeping these fishes from moving into the Atlantic. If sea surface temperatures greater than $23 \mathrm{C}$ are optimal for black marlin (Nakamura, 1975), and no surface temperature as high as $23 \mathrm{C}$ extends beyond the Cape of Good Hope into the Atlantic Ocean (Penrith and Cram, 1974), the Cape of Good Hope may be a barrier for most black marlin.

The answers to the last three questions are not available at this time primarily because the fossil record for marlins is poor. I have examined vertebrae found in the Middle Miocene of the Calvert Formation, Maryland. Although those specimens of Makaira have not been thoroughly studied, they probably cannot be identified to species. In addition, some of the rostra (described and undescribed) from varions fossil localities in the United States bordering the western Atlantic belong to the genus Makaira, but they probably cannot be assigned to species either. Unfortunately, the discovery of $M$. panamensis, like the other fossil material, does not aid in explaining the distribution pattern of living marlins.

Certain paleoecological data do provide clues to the answers of the questions posed above. It is likely that warmer ocean temperatures existed in the Eocene-Pliocene times along the Atlantic coast of Europe (Schwarzbach, 1961) and in Eocene and Miocene times along the Atlantic coast of South Africa (Gill, 1961). Thus, the tip of South Africa probably did not serve as a barrier to the black marlin during the Tertiary. The Isthmus of Panama was an island chain throughout the Miocene (Malfait and Dinkelman, 1972) and probably offered no barrier to the movement of large tropical, oceanic fishes into the Atlantic Ocean. Perhaps, the black marlin was not in existence when conditions for colonizing the Atlantic Ocean were more favorable. It may be more recently derived than the blue marlin.

\section{Ack Nowledgments}

Thanks to Bruce Collette, Luis Rivas, C. R. Robins and Frank Whitmore, Jr. for criticizing the manuscript. Special thanks go to the Smithsonian Institution for awarding me travel and expense money to visit the Department of Paleobiology of the National Museum of Natural History, Frank Whitmore, Jr. and Robert H. Stewart supplied information on M. panamensis. Bruce Collette and Robert Purdy furnished me specimens in their custody. My gratitude goes to Jacques Blot (MNHNP), Peter Bultynck (IRSNB) and Colin Patterson (BMNH) for providing research space and ac- 
cess to their collections. The Cal Poly AudioVisual Department did all photographic work. Diana Crawford deserves credit for her excellent secretarial assistance.

\section{Literature Cited}

Arambovrc, C. 1927. Les poissons fossiles d'Oran. Materiaux pour la carte géologique de L'Algéric, lst Serie, Paléontologie Algérie, No. 6.

BarnoLANI, G, 1910. L'Histiophorus herschelii (Gray) nel teriario superiore. Paleontographia Italica 16:122.

Berky, E. W. 1917. A sailfish from the Virginia Miocenc. Amer. J. Sci. 43:461-464.

CASIER, E. 1966. Faune ichthyologique du London Clay. British Museum (Natural History). London I.

COpE, E. D. 1869. Descriptions of some extinct fishes previously unknown. Proc. Boston Nat. Hist. Soc. 12:310.

Fifrstine, H, L. 1974. The paleontology of billfish -the state of the art, p. 34-44. In: Proceedings of the International Billfish Symposium KailuaKona, Hawaii, 9-12 August 1972. Part 2. Review and contributed papers. R. Shomura and F. Wil. liams (eds.), NOAA Tech. Rpt. NMFS SSRF-675

- - AND S. P. Applegate. 1968. Billfish remains from southern California with remarks on the importance of the predentary bone. Bull. So. Calif. Acad. Sci, 67:29-39.

Fowler, H. W. 1911. A description of the fossil fish remains of the Cretaceous, Eocene, and Miocene formations of New Jersey. Geol. Survey, N.J., Bull. 4.

Gul, E. D, 196il. The climates of Gondwonaland in Kainozoic times, p. 332-353. In: Descriptive paleoclimatology. A. Naim (ed.), Interscience Publ. Inc, N.Y.

GRAY, J. E. 1838. Description of a new species of Tetrapturus from the Cape of Good Hope. Ann. Mag. Nat. Hist. 1(36):31:

GrFGory, W. K, 1933. Fish skulls, a study of the evolution of natural mechanisms. Trans. Amer. Phil. Soc. 23(2): $\mathrm{i}-\mathrm{vii}+75-481$

- - And G. M. Conrad. 1937. The comparative osteology of the swordfish (Xiphias) and the sailfish (Istiophorus). Amer. Mus. Novitates 952.

Howard, J. K., and S. Ueyanagi. 1965. Distribu. tion and relative abundance of billfishes (Istiophoridac) of the Pacific Occan. Studies Trop. Oceanogr. Miami 2.

Hussakof, L. 1908. Catalogue of types and figured specimens of fossil vertebrates in the American Muscim of Natural History. Part 1-Fishes. Bull. Amer. Mus. Nat. Hist. 25.

LACÉpìne, B. G. E. 1802. Histoire naturelle des poissons. 4:689-697.

LAWLeY, R. 1876. Nuovi studi sopra ai pesci ed altri vertebrati fossili delle colline Toscane Firenze.

LEIDY, J. 1855. Indications of twelve species of fossil fishes. Proc. Acad. Nat. Sci. Philadelphia $7: 395-397$.

- 1860. Xiphias robustus. In: F. S. Holmes Post-Pleistocene fussils of South Carolina. Russel and Jones, Charleston, S.C.
Leriche, M. 1926. Les poissons néogénes de la Belgique. Mem. Mus. Roy. Hist. Nat. Belgique $32: 365-472$.

Maleat, B. T. and M. G. Dinkeiman. 1972. Circum-Caribbean tectonic and igneous activity and the evolution of the Caribbean plate. Bull Geol. Soc. America 83:251-272.

Marsh, O. C. 1870. Notice on some new Tertiary and Cretaceous fishes. Proc. Amer. Assoc. Adv. Sci.:227-230.

NAKAMURA, I. 1974. Some aspects of the system atics and distribution of billfishes, p. 45-53. In: Proceedings of the International Billfish Sym posium Kailua-Kona, Hawaii, 9-12 August 1972 Part 2. Review and contributed papers. R. S Shomura and F. Williams (eds.), NOAA Tech. Rpt. NMFS SSRF -675 .

- 1975. Synopsis of the biology of the black marlin Makaira indica (Cuvier), 1831, p. 17-27. In: Proceedings of the International Billfish Sym posium Kailua-Kona, Hawaii, 9-12 August 1972. Part 3. Species Synopses. R. S. Shomura and F. Willians (eds.), NOAA Tech. Rpt. NMFS SSRF. 675.

T. IWAI AND K. Matsubara. 1968. A review of the sailfish, spearfish, marlin, and swordfish of the world. Misaki Marine Biol. Inst., Kyoto Univ., Spec. Rpt. 4.

PenRth, M. J., and D. L. Cram. 1974. The Cape of Good Hope: A hidden barrier to billfishes, $p$ 175-187. In: Proccedings of the International Billfish Symposium Kailua-Kona, Hawaii, 9-12 August 1972. Part 2. Review and contributed papers, R. S. Shomura and F. Williams (eds.) NOAA Tech. Rpt. NMFS S5RF-675.

Rivas, L. R. 1956. Definitions and Methods of measuring and counting in the billfishes (Istiophoridae, Xiphiidae). Bull. Mar. Sci. Guif and Caribbean 6:18-27.

- 1975. Synopsis of biological data on blue marlin, Makaira nigricans Lacépede, 1802, p. 1-16. In; Proceedings of the International Billfish Symposium Kailua-Kona, Hawaii, 9-12 August 1972. Part 3. Species Synopses. R. S. Shomura and F. Williams (eds.), NOAA Tech. Rpt. NMFs SSRF-675.

Ronins, C. R., AND D. P. DE SYLVA. 1960. Description and relationships of the longbill spearfish, Tetrapturts belone, based on western North At lantic specimens. Bull. Mar. Sci. Gulf Caribbean 10:388-419.

Schwarzbach. M. 1961. The Climatic history of Europe and North America, p. 255-291. In: Descriptive paleoclimatology. A. E. M. Nairn (ed) Interscience Publ. Inc., N.Y,

VAN BENEDEN, P. J. 1871. Recherches sur quelques poissons fossiles de Belgique. Bull. Acad. Roy. Sci. Belgique 31:498-518.

Woopking, W. P. 1957. Geology and paleontology of Canal Zone and adjoining parts of Panama. Geology and description of Tertiary mollusks (gastropods: Trochidae to Turritellidae) US. Geol. Survey Prof. Pap. 306-A:1-145.

- 1970. Gtology and paleontology of Canal Zone and adjoining parts of Panama. Descriptive of Tertiary mollusks (gastropods: Eulimidae, Marginellidae to Helminthoglyptidae). Ibid. Pap. $306-\mathrm{D}: 322-452$. 
1973. Geology and paleontology of Canal Zone and adjoining parts of Panama. Description of Tertiary mollusks (additions to gastropors, scaphopods, pelecypods: Nuculidae to Malleidae). Ibid. 306-E:453-539.

WoodwARD, A. S. 1901. Catalogue of the fossil fishes in the British Museum (Natural History). vol. 4.
Biologigal Sgiences Department, California Polytechnic State University, San Lurs Obispo, Ciallfornia 93407 and Los Angeles County Museum of Natural History, Exposition Park, los Angeles, California 90007. Accepted 16 March 1977. 